\title{
Od Piotrusia Pana do Tajemnic motyli. Stefania Szuchowa, Zofia Rogoszówna, James Matthew Barrie i inni - historia (prawie) rodzinna'
}

\begin{abstract}
Abstrakt:
Celem artykułu jest przeprowadzenie analizy komparatystycznej pokrewieństw tekstowych łączących debiutancki utwór polskiej pisarki Stefanii Szuchowej zatytułowany Tajemnice motyli (1920) z opowieścią Jamesa Matthew Barriego Peter Pan in Kensington Gardens [Piotruś Pan w Ogrodach Kensingtońskich] (1906), która w literaturze polskiej zaistniała po raz pierwszy w roku 1913 dzięki przekładowi Zofii Rogoszówny jako Przygody Piotrusia Pana. Istotnym kontekstem, który towarzyszy prowadzonym przez autorkę tekstu dociekaniom, jest również niemal nieznana biografia Szuchowej, pisarki debiutującej w dwudziestoleciu międzywojennym, będącym w Polsce szczególnie intensywnym okresem w rozwoju oryginalnej oraz przekładowej twórczości literackiej dla dzieci. Analizę filiacji tekstowych między utworami Szuchowej i Barriego uzupełnia studium porównawcze niezwykłych podobieństw ilustracji Stefana Norblina, które towarzyszą pierwszemu wydaniu Tajemnic motyli, do grafik Arthura Rackhama z książki Peter Pan in Kensington Gardens.
\end{abstract}

\section{Słowa kluczowe:}

Arthur Rackham, dwudziestolecie międzywojenne, ilustracja książkowa dla dzieci, intertekstualność, James Matthew Barrie, literatura brytyjska, literatura dziecięca, literatura polska, Peter Pan in Kensington Gardens [Piotruś Pan w Ogrodach Kensingtońskich], przekład, Stefan Norblin, Stefania Szuchowa, Tajemnice motyli, Zofia Rogoszówna

* Aleksandra Wieczorkiewicz - mgr, przygotowuje rozprawę doktorską w Instytucie Filologii Polskiej Wydziału Filologii Polskiej i Klasycznej Uniwersytetu im. Adama Mickiewicza w Poznaniu dotyczącą polskiej recepcji przekładowej anglojęzycznej literatury dziecięcej tzw. „złotego wieku”. Kontakt:wieczorkiewicz@amu.edu.pl.

1 Artykuł powstał w ramach grantu Etiuda 7 Narodowego Centrum Nauki - projekt nr 2019/32/T/HS2/00116 pt. Polska recepcja przekładowa dzieł trojga pisarzy „złotego wieku” anglojęzycznej literatury dla dzieci - George'a MacDonalda, Jamesa Matthew Barriego oraz Cicely Mary Barker. 


\section{From Peter Pan to The Secrets of Butterflies: Stefania Szuchowa, Zofia Rogoszówna, James Matthew Barrie, and Others - (Almost) a Family Story}

\section{Abstract:}

The aim of the article is to conduct a comparative analysis of intertextual filiations between a debut book of Polish writer Stefania Szuchowa, titled Tajemnice motyli [The Secrets of Butterflies] (1920), and James Matthew Barrie's Peter Pan in Kensington Gardens (1906) which first appeared in Poland in 1913 as Przygody Piotrusia Pana [Peter Pan's Adventures] thanks to the translation by Zofia Rogoszówna. As an essential context to this study, the author of the paper presents an almost unknown biography of Szuchowa who debuted as a writer during the interwar period - a prolific and intensive time in Polish publishing for children, including both original and translated books. This analysis of intertextual relations connecting the works by Barrie and Szuchowa is supplemented by a comparative study of striking resemblances between Stefan Norblin's illustrations to the first edition of Tajemnice motyli and Arthur Rackham's graphics to Peter Pan in Kensington Gardens.

Key words:

Arthur Rackham, interwar period, children's book illustration, intertextuality, James Matthew Barrie, British literature, children's literature, Polish literature, Peter Pan in Kensington Gardens, translation, Stefan Norblin, Stefania Szuchowa, Tajemnice motyli [The Secrets of Butterflies], Zofia Rogoszówna

\section{Wprowadzenie. „Dziecięce” dwudziestolecie}

Wiatr od Wisły leci górą.

W atramencie maczam pióro.

Wiatr kołacze w me okienko.

Piszę.

- tak zaczyna się utwór otwierający Psotki i śmieszki, jeden z tomików poetyckich Janiny Porazińskiej (1955, s. 5) zawierający wybór z międzywojennej twórczości tej pisarki. Wiersz powstaje jakby z podmuchu wiatru od strony rzeki i w twórczym porywie przelewa się na papier w słowie: „Piszę”. W tych kilku liniach wyczuwa się rozmach, swobodę i suwerenność - pełną energii wolność, która każe chwytać raczej za pióro niż za broń, opowiada się raczej po stronie błękitu atramentu, a nie - czerwieni krwi. To wszystko staje się możliwe dopiero w okresie, w którym Polska ponownie pojawia się na mapach Europy i trwa dwudziestolecie międzywojenne - czas dynamicznego i bodaj najpełniejszego rozkwitu polskiej literatury dla dzieci, gdy tworzą jej wielcy przedstawiciele: 
Jan Brzechwa, Janusz Korczak, Maria Kownacka, Kornel Makuszyński, Janina Porazińska, Zofia Rogoszówna, Ewa Szelburg-Zarembina, Julian Tuwim i inni.

Rok 1918 przyniósł nie tylko wyzwolenie kraju spod zaborów, lecz także zwolnienie literatury - również dziecięcej - z obowiązków wobec narodu. Wraz z odzyskaniem niepodległości wielu twórców i krytyków zaczęło zdawać sobie sprawę z potrzeby stworzenia nowego modelu pisarstwa dla młodego pokolenia, który przystawałby do zmienionych i wciąż zmieniających się realiów powojennej Polski - modelu, który uwzględniłby zarówno nowe dążenia społeczne, jak i nowe potrzeby światopoglądowe i artystyczne. Zygmunt Ziembiński (1928) pisał o konieczności wyzwolenia się z literatury „czasów niewoli”, w której „smutek i przygnębienie rozlały się [...], nie szczędząc najmłodszych czytelników", a przy tym głosił potrzebę przełamania pesymizmu oraz wyjścia z kręgu „idei ofiarnictwa” w stronę afirmacji rzeczywistości, budowania nowych ideałów opartych na „radości życia, poczuciu siły i twórczości” (s. 149), a w literaturze dziecięcej - na wrażliwości dziecka.

W dwudziestoleciu międzywojennym coraz wyraźniej dochodzą też do głosu opinie, iż twórczości dla młodych odbiorców nie należy widzieć jako tworu pośledniejszego od literatury dorosłej i niemogącego wchodzić z nią w twórczy dialog, lecz trzeba w niej dostrzec pełnoprawną dziedzinę artystyczną:

Czas najwyższy, ażeby książki dla dzieci i młodzieży, ten prawdziwy czwarty stan sztuki, znalazły obywatelstwo w dziejach literatury, ażeby były rozpatrywane z tą samą sumiennością i przy użyciu tak samo poważnych kryteriów - jak każde inne ${ }^{2}$.

Taki pogląd wyraziła Maria Dąbrowska $(1929$, s. 6) pod koniec trzeciej dekady ubiegłego stulecia na łamach pisma Świat Książki, lecz przecież nie była to idea nowa - ponad dwadzieścia lat wcześniej, a więc jeszcze w okresie Młodej Polski, Stanisław Karpowicz i Aniela Szycówna (1904) dobitnie postulowali zrównanie literatury dziecięcej i uniwersalnej - a nawet nie tyle zrównanie, ile dostrzeżenie, że ta pierwsza stanowić powinna integralną i nieodłączną część tej drugiej. W formie swoistego manifestu ten pogląd ujęli redaktorzy wspomnianego Świata Książki, wydawanego pod redakcją Jakuba Mortkowicza (1929):

2 Istotne, że Dąbrowska (1929) postuluje de facto zmianę postawy krytyki literackiej, która „może zapełniać całe kolumny na temat najlichszej książki »dla dorosłych«, ale [nie] uważa za godne swego pióra zastanawiać się nad elementami artyzmu książek dziecinnych, choćby to był nawet artyzm najwyższej próby" (s. 6). 
Zeszyt ten niemal w całości poświęcamy dobrej [wyróżnienie oryginalne] książce dla dzieci i młodzieży. Pragniemy dla niej wywalczyć prawo obywatelstwa w literaturze ogólnej. Żądamy, aby oceną jej kierowały te same wymagania, jakie stosujemy przy ocenie każdej innej literackiej książki. Treść i forma, konstrukcja i język, myśl i słowo muszą tu być czynnikami, składającemi [pisownia zgodna z oryginałem] się na dzieło o bezwzględnej wartości artystycznej, przekonywającej niezależnie od jakichkolwiek postulatów pedagogicznych. Tylko taka bowiem książka, działając na umysł, wyobraźnię i uczucia, kształci nowe pokolenie, kulturalnego i wrażliwego czytelnika (s. 3).

W tym manifeście pobrzmiewa już nie tylko chęć dowartościowania literatury dziecięcej względem dorosłej, lecz przede wszystkim wyraźne przekonanie o równoważności tych dwóch dziedzin. Więcej nawet: jest to także przeświadczenie o ich wzajemnej zależności, w której miejsce ważniejsze zajmuje literatura dla młodego pokolenia, gdyż bez dobrej książki dla dzieci (czyli bez poważnego traktowania odbiorcy dziecięcego) nie można oczekiwać wykształcenia się wrażliwych czytelników książki dorosłej mających odpowiednio wyrobiony literacki smak ${ }^{3}$. Nic dziwnego, że pod powyższym manifestem podpisali się w swoich artykułach wielcy twórcy literatury dziecięcej i dorosłej: Stefania Beylinówna - tłumaczka baśni Hansa Christiana Andersena, Maria Dąbrowska czy Janusz Korczak.

Dwudziestolecie międzywojenne to również czas przyspieszonego kształtowania się polskiego rynku wydawniczego, na którym - prócz zasłużonych dla czytelnictwa przedwojennych oficyn, takich jak wydawnictwa M. Arcta czy Gebethnera i Wolffa - pojawiły się nowe, prężnie działające firmy, m.in. Wydawnictwo J. Mortkowicza, Nasza Księgarnia, Rój, Księgarnia św. Wojciecha czy Wydawnictwo J. Przeworskiego. Szczególnie wyróżnia się tu oficyna Mortkowicza, w której opiekę nad działem literatury dziecięcej sprawowała Janina Mortkowiczowa, znakomita redaktorka i tłumaczka dbająca o dobór i jakość publikacji dla najmłodszych czytelników w myśl zasady: „Dajmy dzieciom to, co mamy najlepszego" (Mortkowicz-Olczakowa, 1962, s. 154). Warta podkreślenia jest właśnie owa jakość książek, które miały być nie tylko „zajmujące, pisane przez najlepszych autorów”, lecz także „drukowane starannie na dobrym papierze" (b.a., 1928, s. 60). W okresie międzywojennym można bowiem obserwować wzrastającą dbałość wydawców o szatę graficzną publikacji z zakresu

3 W tym samym duchu pisała Ewa Szelburg-Zarembina (1934/1979) w szkicu Kilka uwag o literaturze dla dzieci: „Pamiętajmy, że bez przyzwyczajenia dziecka do dobrej książki »dziecinnej« nie zdobędziemy dorosłego człowieka dla dobrej książki »dorosłej«. Więcej - nie zdobędziemy go dla nowego, pięknego, owocnego życia” (s. 404). 
literatury dziecięcej, do czego przyczyniły się, z jednej strony, rozwój technologii graficznych, z drugiej zaś - twórczość wybitnych artystów, takich jak Stefan Norblin, Zofia Stryjeńska czy Franciszka Themerson. Literatura przekładowa natomiast - chociaż nie tylko ona - wydawana była z ilustracjami znakomitych twórców zagranicznych.

Mówiąc o „dziecięcym” dwudziestoleciu, nie sposób pominąć właśnie pola twórczości translatorskiej, na którym w tych czasach działało wielu doborowych tłumaczy i tłumaczek z różnych języków: Rozalia Bernsteinowa, Stefania Beylin, Wanda Kragen, Maria Kreczowska (właśc. Feldmanowa), Franciszek Mirandola (właśc. Pik), Janina Mortkowiczowa, Zofia Rogoszówna, Marceli Tarnowski, Irena Tuwim czy Janina Zawisza-Krasucka. Nowe prądy, kierunki i formy, a przede wszystkim odświeżający sposób myślenia o piśmiennictwie dla dzieci jako pełnoprawnej dziedzinie sztuki, trafiały na podatny grunt polskiej literatury dla najmłodszych (zdominowanej dotąd przez dydaktyzm, moralizatorstwo i cele wychowania patriotycznego), ale nie brały się przecież znikąd. To właśnie tłumaczone na język polski arcydzieła literatury zagranicznej stanowiły cenny impuls dla twórczości rodzimej; przede wszystkim jednak dostarczały jej one potrzebnych wzorców literackich. Znaczenie przekładów - także dla rozwoju wartościowego czytelnictwa i dojrzałych czytelników dostrzegali zresztą pedagodzy oraz krytycy literaccy dwudziestolecia. Na przykład Ludwik Bandura (1930) pisał:

Perły literatury dziecięcej obcych narodów należałoby przetłumaczyć, gdyż w literaturze rodzimej dziecko uświadamia sobie wartości narodowe, pogłębia się jego narodowość! W obcej literaturze dziecko wchłania pierwiastki odmienne od naszej indywidualności, rozrasta się w nim pod jej wpływem nowy człowiek. Przez literaturę i sztukę obcą bliższą stanie mu się dusza innych narodów. Budzić się w nim będzie sympatia do najwznioślejszych strun tej duszy, nauczy się szanować obcych (s. 786).

Od początku XX wieku rzeczywiście obserwować można znaczne ożywienie działalności translatorskiej skupionej na tekstach, które dziś uważamy za światową klasykę dla młodych odbiorców - szczególnie zaś należących do obszaru literatury języka angielskiego ${ }^{4}$. Wydawcy i twórcy poszukiwali inspiracji wśród

4 W okresie międzywojennym „przekłady stanowiły około $20 \%$ produkcji książek dla dzieci, wśród nich pierwsze miejsce zajmowały tłumaczenia z języka angielskiego, które wnosiły ożywcze prądy do polskiej twórczości dla dzieci dzięki cechom takim jak optymizm, humor i niczym nie skrępowana [pisownia zgodna z oryginałem] fantazja" (Adamczyk-Garbowska, 1988, s. 42). 
pojawiających się coraz liczniej utworów zagranicznych: spragnieni wolności, wyobraźni, swobodnego udziału fantazji w kreowaniu tekstowego świata, baśniowości wplecionej w rzeczywistość, humoru, nonsensu i zabawy słowem oraz prawdziwej beztroski i lekkości, sięgali po świeżo wydane przekłady m.in. arcydzieł literatury anglojęzycznej, w których w szczególny sposób ucieleśniały się wszystkie te kategorie (Białek, 1979, s. 114). Okres największego, jak sądzę, rozkwitu polskiej literatury dla dzieci, rozpoczynający się w dwudziestoleciu międzywojennym, zbiega się w czasie z dekadami, w których uprawiano intensywną twórczość przekładową z angielskiej klasyki dziecięcej (lub też następuje bezpośrednio po nich $)^{5}$.

„Dziecięce” dwudziestolecie to zatem wybitni twórcy i tłumacze, których dzieła do dziś kształtują nasz kanon literacki. To także znakomite wydawnictwa, doskonali ilustratorzy oraz starannie i pięknie wydane książki, spełniające przywołany już postulat o „bezwzględnej wartości artystycznej” - jednym słowem: pokaźne dziedzictwo literackie, z którego zbiorowa pamięć przechowała zaledwie ułamek. Pośród wielkich nazwisk przewijają się bowiem postaci twórców, których życie oraz dzieła osunęły się w niepamięć - kto wie, czy z ich własnej winy czy przez przeoczenie potomnych. W tym szkicu chciałabym zająć się zapomnianą książką dwudziestolecia i jej zapomnianą autorką: Stefanią Szuchową, która w 1920 roku debiutowała zbiorem Tajemnice motyli. To jedno dzieło skupia w sobie wszystkie wątki, które poruszyłam wyżej: wątek przekładowy i filiacyjny - gdyż w Tajemnicach motyli można się dopatrzyć inspiracji opowieścią Peter Pan in Kensington Gardens Jamesa Matthew Barriego z 1906 roku, która w 1913 roku ukazała się jako Przygody Piotrusia Pana w przekładzie Rogoszówny ${ }^{6}$; wątek artystyczno-graficzny - ponieważ baśni towarzyszą niezwykłej urody ilustracje Stefana Norblina, w zadziwiający sposób podobne do grafik Arthura Rackhama ozdabiających oryginalną edycję dzieła Barriego; wreszcie, z oczywistych względów, wątek literacki. Będzie to zatem opowieść o pewnego rodzaju powinowactwach i rodzinnych podobieństwach: między tekstami, lecz także - być może - między ludźmi.

\footnotetext{
5 Warto zauważyć, że badania poświęcone wpływom, jakie literatura przekładowa wywiera na literaturę rodzimą danego języka, Monika Adamczyk-Garbowska (1988, s. 34-36) włącza w swój trójstopniowy model krytyki przekładu na poziomie socjologiczno-literackim.

6 Prócz wersji Rogoszówny istnieją jeszcze dwa polskie tłumaczenia utworu Peter Pan in Kensington Gardens: przekład Macieja Słomczyńskiego z 1991 roku zatytułowany Piotruś Pan $w$ Ogrodach Kensingtońskich oraz noszące taki sam tytuł tłumaczenie autorki niniejszego artykułu, wydane w roku 2018.
} 


\section{Stefcia buntowniczka}

Z kompendiów, opracowań i leksykonów literatury dla najmłodszych o Stefanii Szuchowej dowiadujemy się niewiele. Jolanta Kowalczykówna (2002, s. 381) w haśle ze Słownika literatury dziecięcej i młodzieżowej określa ją jako pisarkę oraz autorkę słuchowisk dla dzieci i młodzieży, notuje najważniejsze pozycje książkowe, wspomina o współpracy z Polskim Radiem oraz czasopismami dla dzieci (Płomyczek, Świerszczyk, Dziatwa i inne), krytyce literackiej, a także o Nagrodzie Prezesa Rady Ministrów z 1959 roku za twórczość dla dzieci. Bardziej wyczerpujący okazuje się paradoksalnie Polski słownik biograficzny. Z zamieszczonego w nim hasła, ponownie autorstwa Kowalczykówny (1996, s. 20-21), wynika, że Szuchowa była również pedagogiem, zadebiutowała w prasie dziecięcej i młodzieżowej, ogłaszała wiersze, opowiadania, recenzje i artykuły - głownie dotyczące literatury dziecięcej - w czasopismach takich jak Bluszcz czy Kobieta Współczesna, a epizodycznie zajmowała się także przekładem: z rosyjskiego przetłumaczyła opowiadanie albańskie Strach ma wielkie oczy (Szuchowa, 1959a) oraz Wyprawę na poziomki Walentina Katajewa (1940/1963). Polski słownik biograficzny nie pomija również elementów z życia pisarki, które rozpoczęło się jeszcze w stuleciu XIX i trwało przez obie wojny światowe (przedzielone barwnym dwudziestoleciem międzywojennym) aż po późne lata Polski socjalistycznej. Jednak najwięcej o Szuchowej dowiadujemy się ze źródła prywatnego - wspomnień jej siostrzenicy Magdaleny z Bojanowskich Kozarzewskiej (2009), która o „Cioci Stefci” (s. 53) pisała z ciepłem i serdecznością, lecz nie bez gawędziarskiej swady.

Stefania przyszła na świat w Warszawie 16 września roku 1890, gdy wiek pary i żelaza miał się już wprawdzie ku końcowi, lecz niewielu jeszcze spodziewało się, co przyniesie kolejne stulecie. Była córką Edwarda Hamana, melomana i pracownika warszawskiej Hipoteki, oraz Stanisławy z Loberów Hamanowej, młodej pomocnicy modystki, obdarzonej pięknym sopranem. Rodzinna legenda głosi, że ojciec Stefanii najpierw usłyszał głos panny Stanisławy w jednym z warszawskich kościołów, a dopiero później - zachwycony wokalnym odkryciem - odnalazł jego właścicielkę, w której natychmiast się zakochał i którą poślubił (Kozarzewska, 2009, s. 243-244). Stefania była środkowym z trojga dzieci Hamanów: pierwsza na świat przyszła Irena, która odziedziczyła piękny głos matki i zamiłowania muzyczne ojca, a dwa lata po Stefci - Stanisław, z którym pisarka przez całe życie była silnie związana. To on był zresztą najlepszym towarzyszem jej dziecięcych zabaw - Kozarzewska (2009) przytacza anegdotę z życia rodzeństwa, która w sposób szczególny oddaje charakter kilkuletniej bohaterki: 
Nie wiem, w jakim wieku byli oboje, gdy Stasiek zażądał od Stefci wyjaśnienia, skąd się biorą dzieci. „Autorytet”, sam niepewny prawdy o bocianach, wyjaśnił: „Jeśli ludzie chcą mieć dziecko, to idą po specjalne pozwolenie do generała-gubernatora i z tym pozwoleniem jadą do specjalnej kopalni. Tam dają im dziecko”. Brat pomyślał i orzekł: „Kłamiesz, gdyby tak było, można by sobie wybrać chłopca albo dziewczynkę. A przecież nigdy rodzice nie wiedzą, co będą mieli”. Stefcia niezrażona odrzekła: „Tam dzieci leżą w pokładach. Dostaje się pierwsze z brzegu i żadnego wybierania nie ma" (s. 244).

Opowiastka - zabawna sama w sobie - dobrze pokazuje pierwsze rysy kształtującego się charakteru przyszłej pisarki: jej bujną wyobraźnię, zdolność i łatwość fantazjowania, samodzielność myślenia, przekorny i żywy temperament, które w przyszłości zaowocują dziecięcymi opowieściami w druku i w słowie mówionym. Zaowocują one jednak również wieloma perypetiami „na drodze” do twórczości - dorastająca Stefcia jawi się we wspomnieniach siostrzenicy jako prawdziwa buntowniczka, niepokorna i buńczuczna „panna z mokrą głową”, jak żywcem wyjęta z powieści Makuszyńskiego (1932). Choć w szkole pani Walickiej dla dziewcząt uczyła się dobrze (szczególnie pasjonowały ją przedmioty humanistyczne i przyrodnicze, kontynuowane również w dalszej edukacji - te zainteresowania widać w jej późniejszej twórczości dla dzieci, do której przeniknęło wiele z zachwytu naturą i otaczającym światem), to popadała w niekończące się szkolne tarapaty. Raz pod nieobecność nauczyciela sparodiowała ponoć przemowę księdza katechety, z którym często wiodła płomienne dyskusje, a który nie przestawał cierpliwie przestrzegać swoich pupilek: „Pamiętajcie panienki, że ażury som rzeczom zgubnom [pisownia zgodna z oryginałem]” (Kozarzewska, 2009, s. 245).

Szkoły w Warszawie nie ukończyła jednak nie ze względu na afront wobec pobożnego przeciwnika frywolnych pończoch czy na grożącą jej „dwóję” z matematyki, lecz z powodu wyjazdu części rodziny do Krakowa, gdzie starsza siostra Irena miała studiować śpiew. Zbuntowana Stefcia została najpierw umieszczona na pensji z internatem, ale po kolejnej niesubordynacji (oświadczyła wprost swojej wychowawczyni, że nie ma o niej wysokiego mniemania ${ }^{7}$ ) zamieszkała razem z matką i siostrą w Krakowie, gdzie już bez dalszych przygód ukończyła szkołę średnią. W roku akademickim 1913/1914 rozpoczęła studia polonistyczne na Wydziale Filologicznym Uniwersytetu Jagiellońskiego, uczęszczała również na wykłady z historii naturalnej. Czerpała z barwnego życia kulturalnego krakowskiej bohemy - zakochała się w pisarstwie Stefana

7 „Słysząc jak [wychowawczyni] co wieczór chrupie jabłka w swoim kąciku za parawanem w sypialni dla dziewcząt, [Stefcia] powiedziała uprzejmie: »Niech pani je, to bardzo dobrze na rozum robi«" (Kozarzewska, 2009, s. 245). 
Żeromskiego, głęboko przeżywała obejrzane w teatrze Wesele (Wyspiański, Walewski, 1901). W tym czasie zakochała się też zresztą, tym razem dosłownie, w Leonardzie Bończy-Stępińskim, słynnym wówczas aktorze, który starał się o rękę jej siostry (Kozarzewska, 2009, s. 246).

Okres krakowski zakończył się gwałtownie wybuchem I wojny światowej. W pierwszych dniach wojennej zawieruchy rodzina Hamanów znalazła się znów razem w Warszawie, a Stefania rozpoczęła pracę w ochronkach i sierocińcach. Wtedy poznała Stanisława Schucha, nieco młodszego od siebie nieśmiałego miłośnika koni, który wywodził się ze starego rodu saskiego osiadłego w Warszawie pod koniec XVIII wieku ${ }^{8}$. Stanisław, oświadczając się o rękę panny Stefci, miał powiedzieć: „Jeżeli mi pani odmówi, zostaną mi tylko konie" (Kozarzewska, 2009, s. 246). Ich ślub odbył się 9 września 1915, w drugim roku trwania Wielkiej Wojny - trzy lata później na świat przyszedł pierwszy syn małżonków, Piotruś, a po dwóch kolejnych urodził się drugi, Stasiek.

To właśnie dzieciństwo synów było dla Stefanii impulsem, który skłonił ją do rozpoczęcia własnej twórczości literackiej: w roku 1920 zadebiutowała opowieścią Tajemnice motyli, podpisaną spolszczoną wersją nazwiska, „Szuchowa", której będzie odtąd zawsze używać na polu artystycznym. Kolejne publikacje - wierszowane Szepty myszek (Szuchowa, 1924) i Gospodarstwo Madzi i Jacka (Szuchowa, 1929) - wydawane były w latach 20. XX wieku, zaś autorka pisała je o dzieciach i z dziećmi - w rodzinie Hamanów i Schuchów nie brakło latorośli, a wspólne wakacje letnie, spędzane w takich majątkach jak Brwinów czy Racot, z pewnością dostarczały pisarce inspiracji, a także pierwszych dziecięcych słuchaczy i słuchaczek, którzy jej opowieści chłonęli jak urzeczeni. Ten okres był dla Szuchowej pełnią życia:

Układała prześliczne bukiety i robiła znakomite desery owocowe. Nakrywała pięknie do stołu i dekorowała go, gdy przychodziły święta lub rodzinne uroczystości [...]. Nie nosiła zegarka, bo nie pamiętała, że trzeba go nakręcać. Nie liczyła pieniędzy, choć wujek prowadził staranne rachunki [...]. Swoje wiersze i książki pisała na pojedynczych stronach papieru, nie robiąc korekty, tylko przepisując wielokrotnie ulepszane wersje, aż do ostatniej. Miała zawsze sterty tych karteczek i czasopism dookoła siebie. Bardzo często spędzała godziny południowe lub popołudniowe w kawiarni, spotykając się z przyjaciółmi, z ludźmi pióra, potem z młodzieżą nam [Kozarzewskiej i jej kuzynostwu] rówieśną, która zwierzała

8 Pradziad Stanisława, architekt Jan Chrystian Schuch, był intendentem ogrodów królewskich Stanisława Augusta Poniatowskiego i założycielem obecnego parku w Łazienkach jego imię nosi dziś warszawska aleja Szucha (Kwiatkowski, 1996, s. 16-17; Schuch-Nikiel, 2009, s. 19-22). 
się jej ze swoich problemów, nazywając ją „kawiarnianym konfesjonałem”. Jednym ze znajomych literatów był Witold Gombrowicz. Ten prześmiewca musiał mieć do niej jakąś szczególną sympatię, bo nie tylko nie częstował jej drwinami i afrontami, ale okazywał szacunek i przynosił jej swoje młodzieńcze utwory do oceny (Kozarzewska, 2009, s. 251-252).

W gronie znajomych i przyjaciół Szuchowej, prócz „prześmiewcy” Witolda (przed którym Stasiek, zazdrosny młodszy syn Stefanii, krył się pod kanapą, żeby „wiedzieć, czego ten pan chce od mamy” - Kozarzewska, 2009, s. 252), są również Maria Dąbrowska, Jerzy Stempowski czy Andrzej Strug. Trwa bujne dwudziestolecie, w którego życiu Szuchowa bierze aktywny udział, ugruntowując swoją karierę pisarską: w latach 30. ubiegłego wieku ,jej nazwisko - jako cienionej autorki dziecięcej - pojawiało się obok nazwiska Porazińskiej, Szelburg-Zarembiny, Marii Kownackiej” (s. 254)․ Jednocześnie dorastali jej synowie. Starszy, Piotruś, był jasnookim chłopcem, który po matce odziedziczył część jej budzącego sympatię, niesfornego temperamentu. W roku 1936 zdał maturę, a po dwóch latach został przyjęty do Szkoły Podchorążych Lotnictwa. Młodszy, Staś, wpisywał się w linię rodzinnych talentów muzycznych: otaczała go atmosfera „cudownego dziecka”, które ze swoim pierwszym koncertem skrzypcowym wystąpiło w wieku lat siedmiu. Wyrastał na młodego wirtuoza, otoczonego zawsze wianuszkiem złotej młodzieży. Oba te życia - w sposób całkowity lub częściowy - miała złamać zbliżająca się II wojna światowa.

Jej wybuch zastał rodzinę Schuchów rozproszoną po różnych podwarszawskich majątkach. Po powrocie do miasta, do częściowo ocalałych domów, wszyscy znów - choć stopniowo - zebrali się wokół mieszkania Stefanii i Stanisława. Najdłużej brakowało Piotra, który w pierwszych dniach wojny został wcielony do piechoty, a po kapitulacji długo i z narażeniem życia wracał do stolicy przez okupowany kraj (Werner, 2009, s. 174-176). Życie w wojennej Warszawie toczyło się wśród trwogi, niepewności i rodzinnych perypetii. Szuchowa martwiła się losami synów, których młodość przeorała wojna: Piotrek pracował jako robotnik i palił się do konspiracyjnej służby wojskowej, Stasiek natomiast wikłał się $\mathrm{w}$ ryzykowne spekulacje i marnotrawił talent muzyczny, który - pozbawiony ukierunkowania - realizował $\mathrm{w}$ recitalach na klatkach schodowych rozbrzmiewających od czasu do czasu utworami Bacha i Vivaldiego. Jednocześnie pisarka nie przestawała tworzyć, choć i na tym polu wojna zebrała swoje pokłosie: w 1944

9 Obok tych pisarek (dodając jeszcze nazwiska Marii Buyno-Arctowej, Marii Dynowskiej, Kornela Makuszyńskiego i Zuzanny Rabskiej) wymienia Szuchową również Józef Zbigniew Białek (1979, s. 95). 
roku w pożarze księgarni Verbum spłonął rękopis przygotowywanego do druku tomiku poetyckiego Po słonecznej smudze, zaginął również manuskrypt dziełka pod tytułem Skąd masz skrzypki (Kowalczykówna, 1996, s. 20). Najgorsze przyszło jednak z wybuchem Powstania Warszawskiego. Rodzina Schuchów spędziła je wprawdzie bezpiecznie, poza miastem, lecz bez najstarszego syna Piotra, który brał udział w walkach i przepadł bez wieści. Jeszcze wiele lat po zakończeniu wojny rodzice powstańca wierzyli, że Piotruś cudem ocalał i pewnego dnia szczęśliwie wróci do domu. Tak się jednak nie stało.

Po wojnie Stefania podjęła współpracę z Polskim Radiem, dla którego przygotowywała słuchowiska dla dzieci ${ }^{10}$. Poza tym wciąż pisała. Publikowała artykuły w prasie dziecięcej, a od 1948 roku znowu zaczęły ukazywać się jej książki, m.in. opowiadania Staszek kupuje nowe buty (Szuchowa, 1948), Sieć i koszyczek (Szuchowa, 1956), Mateuszek na zaczarowanej wyspie (Szuchowa, 1958), Przygoda z małpka (Szuchowa, 1960), która została przetłumaczona na języki niemiecki i holenderski, a także tomy poetyckie: Zimowe szczęście (Szuchowa, 1951), Za mila trzecia (Szuchowa, 1959c), Księżycowe piosenki (Szuchowa, 1960) czy Dziwię się światu (Szuchowa, 1966a). Tchnące nadzieją i radością pisanie dla dzieci w tamtych czasach musiało być dla autorki trudne: nie zdążyła jeszcze pogodzić się z myślą o stracie najstarszego syna, a już młodszy - uwielbiany Stasiek, zaledwie trzydziestoletni - zapadł na gruźlicę i po kilku latach zmarł, osierocając dwóch kilkuletnich synów. Być może właśnie dla tych wnuków Szuchowa pisała w ostatnich latach życia, odnajdując w dziecięcym świecie odblask dawnej beztroski. Zmarła 18 kwietnia 1972 roku w wieku osiemdziesięciu dwóch lat. Na jej grobie na cmentarzu Ewangelicko-Augsburskim w Warszawie pod nazwiskiem widnieje słowo „Pisarka” oraz dopisek: „pracę i twórczość całego życia poświęciła dzieciom”.

\section{Piotruś Pan i motyle z luźnych kartek}

Siedem lat przed publikacją Tajemnic motyli, debiutanckiej książki Stefanii Szuchowej (1920) z ilustracjami Stefana Norblina, w oficynie Mortkowicza zostały wydane Przygody Piotrusia Pana Jamesa Matthew Barriego (1906/1913) w przekładzie Zofii Rogoszówny i z grafikami angielskiego artysty Arthura Rackhama,

10 Słuchowiska autorki powstawały często na podstawie jej utworów (np. Gospodarstwa Madzi i Jacka czy Mateuszka na zaczarowanej wyspie), ale w latach 50. i 60. spopularyzowała również postać koziołeczka z francuskiej baśni poprzez audycję Dobry pomysł Rududu (Szuchowa, Wasowski, 1957). 
zaczerpniętymi z oryginalnej edycji opowieści Peter Pan in Kensington Gardens (Barrie, 1906). Zdziwić by się mogli jednak ci, którzy w książce chcieliby odnaleźć miejsca, przygody i postaci znane z różnych narracji o Piotrusiu i Wendy: Lagunę Syren, piracki statek kapitana Haka, Tygrysią Lilię czy zagubionych chłopców. Pierwsza opowieść o wiecznym chłopcu, którą Barrie przelał na papier, pozornie niewiele ma wspólnego ze słynną „Wyspą Nigdy”" Nibylandią. Piotruś Pan zjawił się najpierw w sześciu rozdziałach książki dla dorosłych zatytułowanej The Little White Bird or Adventures in Kensington Gardens (Barrie, 1902), z której - po sukcesie sztuki teatralnej Peter Pan, or the Boy Who Would Not Grow Up (Barrie, Boucicault, Frohman, 1904), opowiadającej już o przygodach na Nibylandii - lekko i zwinnie "przefrunął” do książki dla dzieci, wydanej przez londyńską oficynę Hodder \& Stoughton jako Peter Pan in Kensington Gardens (Barrie, 1906) ${ }^{12}$.

Ten „pre-Piotrus'”, „Piotruś przed Piotrusiem” - opowieść o życiu wiecznego chłopca przed „Wyspą Nigdy” - rozgrywa się w Ogrodach Kensingtońskich, jednym z królewskich parków Londynu, dobrze znanym Barriemu z codziennych przechadzek. To właśnie tam - do zielonego i ukwieconego serca miasta, oddzielonego od zgiełku szpalerami drzew oraz kratami ogrodzenia, gdzie w ciągu dnia bawią się dzieci, a nocą urzędują tajemnicze fairies - przyfruwa pewnego wieczoru siedmiodniowy chłopiec, który „ucieka od bycia człowiekiem” (Barrie, 1906/2018, s. 19), by zamieszkać na wyspie wśród ptaków. Piotruś, porzucając swój dom rodzinny, zrywa więzy z ludźmi - choć nie zrywa ich całkowicie: staje się „dzieckiem-ptakiem”, dziwną istotą o niepewnej ontologii, „Między-i-Pomiędzy” (Barrie, 1906/2018, s. 26 - przekład mój ${ }^{13}$ ), „Ni to, ni owo” (Barrie, 1906/1913, s. 32 - przekład Rogoszówny), jak określa go Salomon, mądry władca uskrzydlonych mieszkańców Ogrodów Kensingtońskich. Od tego czasu mieszka na położonej wśród wód parkowego jeziora wyspie, która według prywatnej mitologii Barriego stanowi miejsce początków życia, gdyż „jest ojczyzną wszystkich ptaszków, z których wyrastają później chłopcy i dziewczynki” (s. 14). Jednak

11 Nazwa „Wyspa Nigdy” to sięgający głębiej przekład angielskiego Neverland, które powstało ze złożenia słów never - 'nigdy' i land - 'kraj, kraina' (stąd drugi człon polskiej nazwy „Nibylandia”). Cząstka -land pojawia się jednak również w angielskim island - 'wyspa', można więc przypuszczać, że Barrie pod wyspowe is- podstawia Never-, mając na myśli tyleż „Krainę Nigdy”, „Nigdylandię”, co „Wyspę Nigdy”.

12 Rekonstrukcję złożonej historii tekstów literackich związanych z postacią Piotrusia Pana można znaleźć w mojej książce pt. Piotruś Pan w Ogrodach Kensingtońskich Jamesa Matthew Barriego. Kontekst - Interpretacja - Przekład (Wieczorkiewicz, 2018, s. 47-69). W artykule częściowo powtarzam rozważania prowadzone w tej monografii.

13 Wszystkie imiona oraz nazwy własne, o ile nie zaznaczono inaczej, podaję w moim przekładzie. 
nocami, gdy park pustoszeje i zamykają się jego bramy, Piotruś przepływa przez jezioro w swoim Gnieździe Drozda, by bawić się zapominanymi przez dzieci zabawkami i przygrywać tańcom wróżek i elfów. Noc jest bowiem w Ogrodach czasem panowania żywiołów magii: tajemnicze, maleńkie istoty, które w ciągu dnia kryją się wśród kwiatów i korzeni drzew, w „Czasie po Zamknięciu Bram” (taki sam tytuł nosi jeden z rozdziałów opowieści, w przekładzie Rogoszówny: Po dzwonku) obejmują park we władanie i urządzają szalone bale aż do ostatnich godzin nocy. Ogrody po zmroku nie są jednak miejscem bezpiecznym dla zabłąkanych dzieci, które mogą "zginąć z powodu zimna i ciemności, zanim Piotruś zdąży nadjechać" (Barrie, 1906/2018, s. 93). Autor pisze:

Już kilka razy się spóźnił, a zawsze, kiedy widzi, że przybył za późno [...], kopie grób dla zagubionego dziecka, a potem stawia malutki nagrobek i skrobie na nim inicjały biedactwa. Zabiera się do tego od razu, ponieważ uważa, że tak właśnie zrobiłby prawdziwy chłopiec. Na pewno widzieliście nieraz te małe mogiłki i pewnie zauważyliście również, że stoją one zawsze parami. Piotruś ustawia je parami, gdyż wydaje mu się, że wtedy są mniej samotne (Barrie, 1906/2018, s. 93).

Peter Pan in Kensington Gardens to niezwykła literacka baśń nie (tylko) dla dzieci - słodko-gorzka opowieść o dzieciństwie i konieczności dorastania, które jest pierwszym etapem śmierci ${ }^{14}$. Ten właśnie tekst w 1913 roku Rogoszówna przetłumaczyła jako Przygody Piotrusia Pana. Aż dziw, że podobne dzieło literackie - tak obce treścią wszystkiemu, co polska konwencjonalna literatura dla najmłodszych uważała za cenne i pożądane (pamiętajmy, że jeszcze pod koniec lat 20. XX wieku Kazimierz Króliński gorszył się łagodną fantazją wierszy Porazińskiej ${ }^{15}$ ) - trafiła

14 O powiązaniu tematyki dorastania i śmierci w utworach Barriego piszą również m.in. Anna Maria Czernow (2018, s. 107-124), Katarzyna Slany (2016, s. 178-193) oraz Karolina Szymborska (2013-2014).

15 Utrwalony przed rokiem 1918 model literatury dziecięcej z różnych względów za największego wroga uznawał fantazję literacką, która miała skutkować niebezpiecznym rozchwianiem dziecięcego umysłu i przynosić opłakane skutki wychowawcze. Podobne przeświadczenie pokutowało jeszcze w dwudziestoleciu: w roku 1927 Króliński krytykował ostro przejawy nawet tak łagodnej fantazji, jak ta z wierszy W Wojtusiowej izbie Porazińskiej (1924). Krytyk pisał: „Do Wojtusia Porazińskiej przemawia kałuża wody na podłodze, rozsypane klepki cebrzyka, kiecki w skrzyni, iskierka w popielniku, nić pajęcza na stosie poduszek - słowem z każdego kąta wyziera doń jakaś tajemnicza złowroga twarz, jakieś straszydło. Czy godzi się - dla pewnych walorów artystycznych otaczać dziecko rojem tajemniczych istot, targać jego nerwy, torować drogę bojaźliwości, tchórzostwu, neurastenii - może nawet samobójstwu? [...] Jaki żołnierz będzie kiedyś z chłopca, który lęka się własnego cienia, boi się nocy i samotności?” (Króliński, 1927/1979, s. 351-352). 
na nasz rynek wydawniczy i została dobrze przyjęta przez krytykę oraz czytelników. Zdziwimy się jednak nieco mniej, gdy liryczny, przepojony melancholią oryginał Barriego zestawimy z przekładem Rogoszówny, nie tylko poddanym zabiegom udomowienia i gęsto obrośniętym deminutywami, lecz również stosującym translatorską cenzurę wobec zakończenia powieści. W swoim tłumaczeniu Rogoszówna pomija bowiem trzy końcowe akapity, które zostawiają czytelnika $\mathrm{z}$ widokiem Piotrusia Pana w roli grabarza kopiącego dziecięce mogiły oraz z gorzkim stwierdzeniem „It is all rather sad” (Barrie, 1906, s. 126), czyli „Wszystko to jest dość smutne" (Barrie, 1906/2018, s. 94). Taka ocena nie oddałaby jednak w pełni sprawiedliwości tłumaczce, która - choć poddała się obowiązującej konwencji literackiej w odniesieniu do tematów uważanych za nieodpowiednie dla dziecięcych uszu - okrasiła swojego Piotrusia Pana wspaniałym humorem (wyraźniejszym nieraz niż humor oryginału) i stworzyła spójny, dostosowany do odbiorcy dziecięcego przekład pisany w urokliwej, przedwojennej polszczyźnie. Rogoszównie - jako tłumaczce i autorce, która stanowi ogniwo łączące prozę Stefanii Szuchowej z twórczością Barriego, a zwłaszcza z jego Piotrusiem Panem - należy się kilka osobnych słów.

Przyszła na świat w roku 1881 lub 1882. Była córką pisarza i publicysty Józefa Rogosza, w którego domu w Zborówku bywało wielu twórców ówczesnej epoki, m.in. Adam Asnyk, Helena Modrzejewska czy Eliza Orzeszkowa. Do „melodyjek”, które wygrywała ofiarowana przez tę ostatnią „skrzyneczka samograjka", sześcioletnia Zosia dopisywała swoje pierwsze dziecinne wiersze (Rogosz-Walewska, 1961, s. 4). Lata wczesnej młodości upłynęły jej w Krakowie, gdzie po śmierci ojca została redaktorką w Głosie Narodu. Był to dla niej także czas zaangażowania społecznego i intensywnej, radosnej „pracy u podstaw". Nie trwało to jednak długo - kres pracom społecznym położyła gruźlica, która zmusiła Zofię do podjęcia leczenia w zagranicznych sanatoriach, ale dała jej także czas na własne pisanie. „Dziwne bywają losy człowieka - zwierzała się pisarka w liście do siostry. - Gdyby nie moja choroba, nigdy nie napisałabym słowa. [...] Teraz, będąc chora, wyżywam się w pisaniu” (s. 4). Pisała wyłącznie o dzieciach lub dla dzieci: jej pierwsza książka, Pisklęta (Rogoszówna, 1910), tytułem pokrewna myśli Barriego o bliskości dzieci i ptaków, była właściwie utworem adresowanym do dorosłych, „mającym odkryć [przed nimi] cud dzieciństwa, nauczyć [ich] prowadzić dialog z dzieckiem” (Heska-Kwaśniewicz, 2005, s. 114), ale badacze pisarstwa Rogoszówny podkreślają, że niemal każdy jej utwór skierowany jest do odbiorcy podwójnego: dziecięcego i dorosłego (s. 114; zob. także Skrobiszewska, 1973, s. 621-631). Jej teksty, dziś już przeważnie zapomniane, pobrzmiewają jeszcze czasem w rymowankach Sroczka kaszkę warzyła (Rogoszówna, 1920a), Tańcowały dwa Michały (Rogoszówna, 
1920b) czy spopularyzowanych tytułach: Klituś bajduś (Rogoszówna, 1925), Koszałki opałki (Rogoszówna, 1928). Co ciekawe - i zbieżne - niektóre z jej opowiadań (Konfitury panny Michaliny, Rogoszówna, 1911; Wesele Kuby, Rogoszówna, 1930) opatrzył grafikami również Norblin, ilustrator dzieł Szuchowej. Rogoszówna tłumaczka przekładała literaturę wyłącznie dziecięcą (choć nie tylko z języka angielskiego): dzieła Clemensa Brentano (Opowieść o Gdakaczu, Gdakuli i Gdakuleńce, 1838/1911), Anatole’a France’a (Zazulka, 1883/1915), Williama Thackeraya (Pierścień i róża, 1855/1913) i rzecz jasna Barriego.

Czas najwyższy powiązać „luźne kartki” z zapiskami o Stefanii Szuchowej, Piotrusiu Panie Barriego i przekładach Rogoszówny, do kręgu rodzinnej opowieści dołączając jeszcze Stefana Norblina (który w dalekiej linii był zresztą rzeczywiście z rodziną Schuchów skoligacony - zob. Werner, 2009, s. 9-12, 136-137). Punktem zbieżnym wszystkich tych wątków jest właściwie zupełnie dziś zapomniana twórczość Szuchowej - przede wszystkim jej międzywojenna opowieść Tajemnice motyli - która okazuje się niezwykle bliska literackim światom Barriego, obecnym w polszczyźnie poprzez przekład Rogoszówny. Ilustracje Norblina do Tajemnic motyli są z kolei jakby żywcem wyjęte ze szkicownika Artura Rackhama, którego grafiki towarzyszyły pierwszemu wydaniu powieści Peter Pan in Kensington Gardens - zbieżność wizji artystów zawiązuje pomiędzy utworami wyraźną nić pokrewieństwa, któremu warto przyjrzeć się bliżej.

\section{Ulotne opowieści dzieciństwa}

Już sama dedykacja Tajemnic motyli - „Hali, Witowi, Stasiowi i Marysi ofiarowuję, a pamięci ich najlepszej Mamusi, Zofii z Szuchów Wernerowej poświęcam - St. S." (Szuchowa, 1920, b.n.) ${ }^{16}$ - wprowadza w atmosferę rodzinnego kręgu i jednocześnie pewnej melancholii, nieobcej i autorowi Piotrusia $P_{a n a}{ }^{17}$. Debiut pisarski Szuchowej, wydany w 1920 roku w Warszawie na-

16 Zofia z Szuchów Wernerowa (przez którą właśnie Schuchowie spowinowaceni byli z Norblinami) była siostrą męża Stefanii, zmarłą tragicznie i przedwcześnie w epidemii hiszpanki. Czwórkę osieroconych przez nią dzieci Szuchowa otaczała opieką przez wiele kolejnych lat (Werner, 2009, s. 248).

17 Również Barrie opatrywał swoje opowieści o Piotrusiu dedykacjami: pierwsza z nich, zawarta w utworze Peter Pan in Kenisngton Gardens i przeznaczona „Dla Sylvii i Arthura Llewelyn Davies oraz dla ich chłopców (moich chłopców)" (Barrie, 1906/2018, b.n.), nakreśla skomplikowaną relację, która już wtedy łączyła pisarza z rodziną Llewelyn Davies (Wieczorkiewicz, 2018, s. 33-45). Z kolei dedykacja z pierwszego książkowego wydania sztuki Peter Pan, or The Boy Who Would Not Grow Up (Barrie, 1928, b.n.), nosząca tytuł 
kładem oficyny Edwarda Wendego i spółki, to właściwie zbiór baśniowych opowiadań spiętych wspólną ramą narracyjną. W Spisie książek poleconych do bibljotek szkolnych z roku 1929 znajdziemy takie „streszczenie” utworu:

Królowa motylków, idąc za radą królewicza chrabąszczy, Bzyka III-go, postanowiła nadać nazwy dotąd bezimiennym swym poddanym i dzieciom. W tym celu każe im lecieć w świat, i zdobywać imiona przez zasługi lub przygody, które niekiedy pozostawiają ślad na ich wyglądzie. Szereg powiastek przedstawia przygody różnych motylków, w których przeważnie odzwierciadla się życie ich ludzkiego otoczenia. Autorka włożyła w opowiadanie dużo sentymentu i poczucia piękna przyrody. Ze stanowiska artystycznego książka jest ładna, wydana z pięknemi [pisownia zgodna z oryginałem] ilustracjami S. Norblina (Ministerstwo Wyznań Religijnych i Oświecenia Publicznego, 1929, s. 305).

Rzeczywiście, pierwsze opowiadanie, zatytułowane Królowa motylków, zakreśla ramę narracyjną całego zbioru: władczyni „fruwającej czeredki” (Szuchowa, 1920, s. 11) wysyła swoich poddanych na poszukiwanie imion, zaś w dzień, „gdy wiosna spotyka się z latem" (s. 13), ma odbyć się wielka Uroczystość (tak właśnie, Uroczystość, zatytułowane jest opowiadanie ostatnie), podczas której motylom zostaną nadane imiona. W kolejnych miniaturach opowiadane są przygody skrzydlatych bohaterów baśni. Imię Perłowca wzięło się stąd, że pomógł sierotce ocalić jej najdroższy skarb przed złą Babą Jagą (Perełki Hanusi), a spośród dwóch motylich braci, Pokrzywnika i Rusałki, pierwszy zdobywa swoje imię w pokrzywach pod wiejską chatką, drugi zaś - na dworze Srebrnej Kropelki, pani jeziora (Dwaj towarzysze). Motylek wierny łące to opowieść o Tęczowcu, nazwanym tak ze względu na miłość, jaką darzył błękitne łąkowe kwiaty - dzwonek i cykorię. Żałobnik usłyszał swoje imię od lilii, która opowiedziała mu historię o utraconym szczęściu (Między liljami), Paź królowej okazał się wiernym sługą swojej władczyni, której pomógł wyswobodzić palec uwięziony w szczelinie wierzby (Jazda przez puszcze), Admirał natomiast odznaczył się wielką odwagą podczas sztormu na jeziorze, zdobywając zarówno imię, jak i „czerwoną wstęgę przez skrzydełka” (Szuchowa, 1920, s. 68; Na samotnej łódeczce). Pawik zyskał miano na zamku małego króla, który w dniu imienin otrzymał w prezencie pawiątko i motyli kokon (Mały król). Na końcu, w osobnym rozdziale, odbywa się narada nad przygotowaniami, a zaraz potem wielka Uroczystość nadania imion. Jako ostatnie motyle przylatują jeszcze Kapustnik, który „obleciał wszystkie kapuściane głowy

To the Five i skierowana do pięciu braci Llewelyn Davies, którymi Barrie zaopiekował się po śmierci ich rodziców, jest już rozbudowaną narracją, pełną wspomnień i nostalgii za minionymi dniami. 
w sadzie” oraz „motyl pierwszy na wiosnę, żółty jak płatki kaczeńca”, któremu królowa nadaje imię Złoty Listek, „chociaż wszystkie dzieci na świecie nazywają go Cytrynkiem" (s. 93).

Jednak w „szeregu powiastek o przygodach motylków” nie do końca „odzwierciadla się życie ich ludzkiego otoczenia” - jak chcieliby autorzy przywołanej wyżej notki ze Spisu książek... Ludzie - jeśli w ogóle pojawiają się w opowieściach, bo w kilku nie ma o nich mowy wcale - występują w nich przeważnie „obok", tworzą swego rodzaju równoległy świat, zawieszony zresztą pomiędzy fantazją a realnością, gdyż nawet w tak „przyziemnym” opowiadaniu jak Peretki Hanusi odnajdziemy elementy baśniowe i fantastyczne. Motyle przefruwają (niczym Piotruś Pan) pomiędzy dwoma światami - „realną” dziedziną człowieka i baśniowym dominium Natury, w którym włada ich Królowa. Podobne współistnienie dwóch światów odnajdziemy w Przygodach Piotrusia Pana, gdzie Park Leśny (w ten sposób Rogoszówna przekłada nazwę Kensington Gardens) staje się przestrzenią we dnie zaludnianą przez bawiące się dzieci, w nocy zaś podległą panowaniu królowej Mab, władczyni elfów - tajemniczego „małego ludku” z Ogrodów Kensingtońskich.

Zdaje się, że to subtelne przeplatanie fikcji i rzeczywistości, tak charakterystyczne dla opowieści Barriego, najbardziej urzekło Szuchową, inspirując ją do snucia lirycznej, onirycznej baśni o skrzydlatych mieszkańcach łąki i lasu. Jednocześnie z opowieści o chłopcu, który nie chciał dorosnąć, pisarka wybiera właśnie świat „maleńkich ludzi”, który zdaje się najsilniej poruszać jej wyobraźnię, tworzyć akord z jej odczuwaniem świata; to nie sama historia Piotrusia Pana, jego ucieczki z domu oraz życia w londyńskim parku leży u podstaw Tajemnic motyli, lecz opowieść Barriego o zaczarowanej, zanurzonej w pięknie przyrody dziedzinie elfów, w której Piotruś zyskuje udział dopiero po pewnym czasie. Świat natury (dwór Królowej motylków, Srebrnej Kropelki, pani jeziora oraz Bzyka, królewicza chrabąszczy), zwyczaje jego mieszkańców oraz język, jakim się o nich opowiada, zostają przez Szuchową "nałożone” na opowieść i język Barriego z Przygód Piotrusia Pana w wersji Rogoszówny. Przyjrzyjmy się dwóm fragmentom - pierwszemu z powieści Barriego o magicznym świecie Ogrodów Kensingtońskich po zmroku, drugiemu z opowiadania Szuchowej o przygodzie motyla Rusałki:

Tłumy najśliczniejszych elfów i elficzek ciągną na bal ze wszystkich stron. Mężowie obejmują czule swoje żony, a kawalerowie ustrojeni w mundury niosą treny dam. Przed orszakiem biegną pachołcy z pochodniami, zrobionemi z gałązek żórawinek. To są latarki elfów. Najpierw damy udają się do garderoby, gdzie zrzucają zasłony i zarzutki, a wdziewają śliczne trzewiczki srebrne. Wszystkie kwiaty 
rosnące wzdłuż Aleji dzidziusiów wychylają główki, stają na palcach i przyglądają się z zachwytem orszakowi zaproszonych; nie posiadają się też z radości jeżeli mogą której z dam pożyczyć szpilki do spięcia oberwanej falbanki. Na najwyższem wzniesieniu siedzi królowa elfów, a za jej tronem stoi Wielki kanclerz [...] (Barrie, 1906/1913, s. 67-68; w całym fragmencie pisownia zgodna z oryginałem).

Ścianki nenufaru rozstąpiły się natychmiast. Pręciki i słupki stały się smuklejsze i zmieniły się w złote kolumny. Światłem miesiąca obudzone wstały wszystkie dziwy wód wiosennych i zaludniły białe, pachnące wnętrze. Na muszelce w cztery zwinne rybki zaprzęgniętej wnet zjechali goście: pani Srebrna Kropelka i pan Pręciutkie Światełko - para duszków rządząca lśnieniem fal. Za niemi wpadło do nenufaru mnóstwo innych duszków, stworzeń, blasków, iskierek... Najwyraźniej szykowało się tu wielkie wesele. Brzmiała daleka muzyka nocy wiosennych, stłumiona i słodka. Iskierki wodne tańczyły same po pustej jeszcze sali. Po kątach duże komary, delikatne jak cienie przygotowywały do tańca swe długie wrażliwe nogi poruszając niemi bezustannie. Maleńkie muszki, mniejsze od wszystkich elfów świata chmurkami kołowały pod sklepieniem (Szuchowa, 1920, s. 31-32) ${ }^{18}$.

Opis wesela na tafli jeziora do złudzenia przypomina przedstawienie balu elfów z opowieści Barriego (same „elfy” wspomniane są zresztą również u Szuchowej) - gdyby zresztą przy toczyć więcej cytatów z Przygód Piotrusia Pana (np. „Trąby weselne zagrzmiały, księżyc wysunął się z chmur, a tysiące par elfów chwyciło się jego promieni i w szalonej radości walcowało dokoła »czarodziejskiego kręgu“" - Barrie, 1906/1913, s. 106-107) lub choćby poszerzyć wyimek z Tajemnic motyli, podobieństw znalazłoby się jeszcze więcej: elfy tańczą w rytm muzyki fletni Piotrusia, której melodia brzmi jak wiosenny śpiew słowika i potrafi sprawić, że zakwitają kwiaty kasztanowca; Srebrna Kropelka pląsa w objęciach swojego partnera tak samo jak królowa elfów z wielkim kanclerzem pod baldachimem z robaczków świętojańskich. Przede wszystkim jednak poetycki język i obrazowanie obu tekstów - Barriego w przekładzie Rogoszówny oraz opowiadań Szuchowej - tworzą nierozerwalną, wręcz bliźniaczą parę.

Charakterystyczne, że Szuchowa zapożycza od Barriego niektóre pomysły na funkcjonowanie baśniowego świata przyrody: Tajemnice motyli rozgrywają się oczywiście za dnia, w przeciwieństwie do opowieści o elfach z Parku Leśnego, które dopiero po zmroku wychodzą ze swoich kryjówek, jednak sama kwestia upływu czasu przedstawiona jest w obu tekstach podobnie. W Przygodach Piotrusia

18 W wydaniu książki z lat 50., przejrzanym i poprawionym przez autorkę, przytoczony fragment staje się jeszcze bliższy przedstawieniu z Przygód Piotrusia Pana, gdyż mowa w nim o „balu”, a nie o „weselu” (Szuchowa, 1920/1958, s. 26). 
Pana Barrie pisze bowiem, że dla małych istot z Ogrodów Kensingtońskich czas płynie szybciej niż dla ludzi - każdy miesiąc jest niczym jeden rok, więc „elfy obchodzą urodziny każdego miesiąca" (Barrie, 1906/1913, s. 72). Identycznym zabiegiem posługuje się Szuchowa (1920), u której rokiem jest każdy dzień - na propozycję królewicza Bzyka, by z wielką Uroczystością poczekać do przesilenia letniego, Królowa motyli woła żałośnie: „Tak długo! Toż to jeszcze piętnaście lat!”, a narrator wtrąca w nawiasie, że: „W życiu motylków dzień jest rokiem” (s. 13).

Krótkie - chciałoby się rzec: ulotne - życie motyli również odnosi się do opowieści Barriego, choć już na wyższym poziomie: metaforycznym, nie tylko treściowym czy wyobrażeniowym. Motyle u Szuchowej (1920) są bowiem silnie powiązane $\mathrm{z}$ obrazem (przemijającego) dzieciństwa i dziecięcości: one same są przez Królową nazywane „jej dziećmi” (s. 9), noszą też wyraźne cechy dziecięcych bohaterów. Tam, gdzie w opowiastkach występują ludzie, są to niemal wyłącznie dzieci (sierotka Hania w Perełkach Hanusi, rodzeństwo wiejskich dzieci w opowiadaniu Dwaj towarzysze, tytułowy bohater rozdziału Mały król), które w jakiś sposób biorą udział w przygodach motyli lub stają się przyczyną i powodem nadania motylego imienia. Samo zdobywanie imion również wpisuje się w symbolikę dzieciństwa - można je przecież rozumieć jako proces dorastania, dojrzewania oraz indywiduacji, w którym z nieukształtowanych jednostek (bezimiennych motyli) wyrastają konkretni bohaterowie, obdarzeni wyjątkową tożsamością; zdobywanie i nadawanie imion jest przecież w wielu kulturach oznaką przejścia z dzieciństwa w stan dorosłości. Czyż zresztą motyle same w sobie nie są piękną i nośną metaforą przemiany - przepoczwarzania się, dojrzewania, metamorfozy? U Szuchowej ta symbolika zawiera $\mathrm{z}$ jednej strony pozytywne wartości; $\mathrm{z}$ drugiej jednak - i tu pisarce blisko do Barriego - historie i przeżycia związane z imionami stają się dla motyli tajemnicami (nie dowiaduje się o nich ogół społeczności, jedynie Królowa), które często niosą w sobie ziarnko goryczy. Tak dzieje się w przypadkach Admirała, który podczas sztormu na jeziorze doświadczył lęku i zwątpienia, i, przede wszystkim, Żałobnika, którego imię oraz kolor związane są z rozpaczą i utratą szczęścia: „Każdy, kto spojrzy na motyla zrozumie, że jego ciemne skrzydła, gdy się chwieje nad kwiatem, to słowa wielkiej tajemnicy dla kwiatu: »Minie twoja słoneczna godzina «" (Szuchowa, 1920, s. 47). To zdanie mógłby przecież napisać James Matthew Barrie, który zresztą pisał je wielokrotnie, choć wyrażone innymi słowami: „Wszystkie dzieci - oprócz tego jednego - dorastają" (Barrie, 1911/2006, s. 5) - i mija nieubłaganie ich (nasza) słoneczna godzina. Dzieciństwo jest ulotne jak motyl, nietrwałe jak przemijająca świeżość kwiatów, które - posłuszne „wielkiej tajemnicy" - więdną, gdy kończy się czas ich kwitnienia. 
Barrie za symbol dzieciństwa obiera ptaki, Szuchowa motyle - choć w jej baśniach i wierszach nie brak obrazów spokrewniających dzieci i ptaki: sama Królowa motyli, „chociaż była dziewczynką, wołała jak ptak” (Szuchowa, 1920, s. 9), natomiast bohaterka liryczna wiersza Fontanna w parku - w którym już sam tytuł przywodzi na myśl Park Leśny z opowieści Barriego w przekładzie Rogoszówny - „myśli tak: / „Czy jestem ptakiem / dziewczynką / czy kwiatem? / Czasem w tak pięknej chwili / można się przecież pomylić...»" (Szuchowa, 1966b, s. 18) ${ }^{19}$, jednak oba te symbole mają ze sobą wiele wspólnego. Mam tu na myśli, po pierwsze, „ulotność”, a więc delikatność oraz egzystencjalną kruchość, po drugie zaś - „lekkość”: zarówno ptaki, jak i motyle posiadają przecież skrzydła, zdolne są podrywać się do lotu i szybować nad ziemią. Podobnie jak dzieci, podpowiada Barrie (1906/1913), które „były ptaszkami, zanim stały się ludźmi, i dlatego są takie dzikie w pierwszych tygodniach po urodzeniu i najwięcej łaskotek mają koło łopatek, tam, gdzie pierwej rosły skrzydełka” (s. 22). Najsłynniejszym „dzieckiem-ptakiem” jest właśnie Piotruś Pan, „wesoły, niewinny i bez serca" (Barrie, 1911/2006, s. 225), który dzięki umiejętności latania potrafi oderwać się od ciężaru dorosłej powagi - pozostaje poza czasem i poza koniecznością dorastania. Beztroska Piotrusia jest w pewien sposób beztroską motyla, który frunąc, rzuca jednak cień na ziemię. Nie dla wszystkich „słoneczna godzina" trwa przecież wiecznie.

Niezwykłego pokrewieństwa tekstów Barriego i Szuchowej - które stało się możliwe dzięki przekładowi Rogoszówny - dopełniają ilustracje Norblina towarzyszące Tajemnicom motyli. Norblin, urodzony w Warszawie w roku 1892 (a więc niemal równolatek Szuchowej), jest artystą, którego twórczość odkrywa się dziś na nowo. Był malarzem:

[...] przede wszystkim uznanym portrecistą przedwojennych elit. Zasłynął ponadto jako autor wyrazistych plakatów, ilustracji do książek, czasopism, także

19 Powojenne wiersze Szuchowej zawierają zresztą o wiele więcej wyraźnych odniesień do tekstu Barriego, świadczących o tym, że pisarka znała ten utwór, a jego lekturę głęboko przeżyła. W tomie Za mila trzecia odnajdziemy np. wiersz pt. Zabawa w parku: „W parku pełno radości, gonitwy i krzyków... / Przed bramą stoi babcia z pękiem baloników" (Szuchowa, 1959d, s. 12) - to chyba nie przypadek, że w Przygodach Piotrusia Pana rozdział pierwszy rozpoczyna się od widoku bramy, a „u wejścia można zamienić parę słów z "panią od baloników»" (Barrie, 1906/1913, s. 2). W innym wierszu, noszącym tytuł Tajemnica, mowa z kolei o krasnoludku, który schował się w tulipanie (Szuchowa, 1959b, s. 7) - u Barriego (1906/1913) natomiast „pewien stary elf [...] na głos Piotrusia porwał się z miejsca i z przeraźliwym krzykiem pobiegł się ukryć za wielki kielich tulipana" (s. 25-26). 
jako projektant winiet i okładek, a nawet strojów teatralnych - słowem wszechstronny artysta dwudziestolecia międzywojennego (Szlązak, 2011, s. 7).

Współcześnie szczególnie zwraca się jednak uwagę na utrzymane w stylistyce art déco egzotyczne malowidła ścienne jego autorstwa w rezydencjach maharadżów, które powstały podczas pobytu artysty w Indiach w latach 1941-1946 (Kasprzak, 2014, s. 109-115; Kłodkowski, 2012, s. 30-32). Norblinowi - ilustratorowi książek dla dzieci (a tworzył grafiki do rozmaitych tekstów różnych autorów, m.in. Hansa Christiana Andersena, Zdzisława Kleszczyńskiego, Kornela Makuszyńskiego czy Zofii Rogoszówny) poświęca się chyba najmniej uwagi, pisze o nim jednak Katarzyna Kulpińska (2011):

Książki dla dzieci Norblin ilustrował elegancką, secesyjną kreską [...]. Z ciekawszych realizacji należy wymienić ilustracje do Tajemnic motyli S. Szuchowej, Złotego pierścienia Z. Urbanowskiej, Bajek J. Ejsmonda, powiastek dla dzieci E. Szelburg-Zarembiny, J. Porazińskiej, J. Colonny-Walewskiej [...] (s. 36).

Nieprzypadkowo Tajemnice motyli pojawiają się wśród czołowych osiągnięć Norblina na polu ilustracji dziecięcej: utrzymane w delikatnej, pastelowej tonacji, lecz odważne pod względem rysunku, zachwycają dynamiką i wdziękiem. Zmysłowa kobiecość Królowej motyli zostaje zestawiona w tańcu z karykaturalną postacią królewicza chrabąszczy, który wzrostem i posturą przypomina chochlika lub gnoma, Admirał stoi na dziobie łódeczki z kory, która płynie po wzburzonej, cętkowanej wodzie, a wszystko to odbywa się w nierzeczywistej przestrzeni wyizolowanej z tła. Tylko graficzne porównanie jest jednak zdolne oddać podobieństwa ilustracji Norblina z książki Szuchowej do grafik Rackhama, które towarzyszyły polskiemu wydaniu Przygód Piotrusia Pana Barriego w przekładzie Rogoszówny. To niemal ta sama kreska, to samo blade tło, te same desenie i fasony sukni, te same gesty, identyczne zestawienie pięknej wróżki-królowej z gnomem-karzełkiem, ten sam wdzięk, lekkość, dynamika, kompozycja przestrzenna i aranżacja.

Na pierwszym zestawieniu ilustracji (rysunki 1 i 2) zwraca uwagę wdzięczna poza Królowej motyli, kłaniającej się królewiczowi i unoszącej suknię tym samym pełnym gracji gestem, który oddał Rackham na grafice $\mathrm{z}$ czwartego rozdziału Przygód Piotrusia Pana, przedstawiającej Królową wróżek pod gałązką głogu. Czerwone owoce zawieszone nad postacią zostały zresztą - jak w lustrzanym odbiciu - powielone na ilustracji Norblina, natomiast suknia Królowej motyli (srebrnoszara, w arabeskowe wzory, z obfitą spódnicą i trenem) wydaje się jakby „zaczerpnięta” z grafiki Rackhamowskiej. 


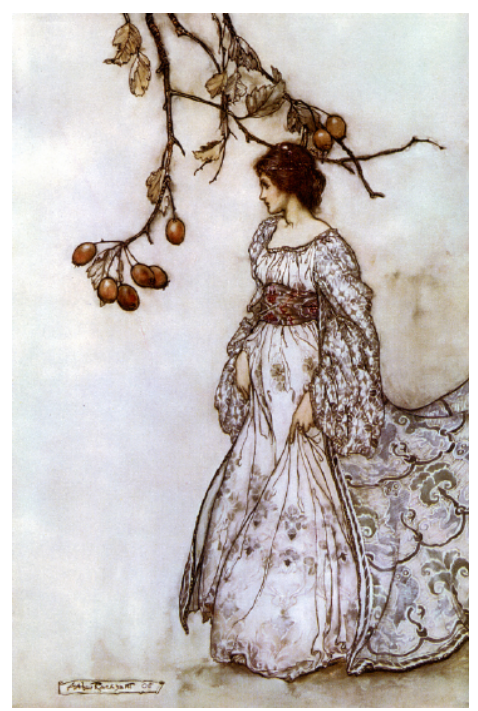

RYSUNEK 1. Arthur Rackham, Looking very undancey indeed (Peter Pan in Kensington Gardens).

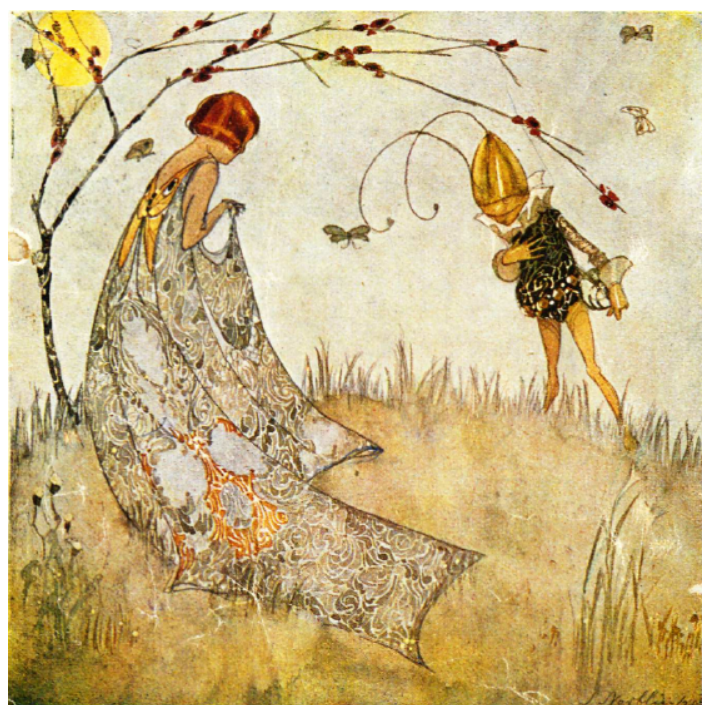

RYSUNEK 2. Stefan Norblin, ilustracja do rozdziału Królowa motylków (Tajemnice motyli).

W kolejnym zestawieniu (rysunki 3 i 4), przedstawiającym sceny tańca, uderza samo podobieństwo ujęć oraz wyboru tekstowego „momentu”, ale także połączenie w tanecznej parze smukłej postaci kobiecej z o połowę niższym tancerzem: małym elfem u Rackhama i podobnym do gnoma królewiczem Bzykiem u Norblina. Wspólna jest również wewnętrzna dynamika obu ilustracji - suknie rozwiewane wiatrem, nogi tancerzy uniesione w podskoku, załamujący symetrię element u góry grafiki: gałązka ognika szkarłatnego (Rackham) i girlanda frunących motyli (Norblin).

Podobną dynamiką odznaczają się też ilustracje $\mathrm{z}$ trzeciego zestawienia (rysunki 5 i 6), przedstawiające sztorm na jeziorze - ciekawe, że dzieło Norblina stanowi znów lustrzane odbicie grafiki Rackhama: łódki płyną i nachylają się w przeciwnych kierunkach, jedna wspina się na fale, druga opada. Żagiel, który na rysunku z Przygód Piotrusia Pana zrobiony jest z nocnej koszulki wiecznego chłopca, znajduje swoje odzwierciedlenie w rozpiętych skrzydłach Admirała, który stoi na dziobie łódeczki, podobnej zresztą bardzo do Gniazda Drozda, w którym płynie Piotruś. Obie ilustracje różnią się dominującą kolorystyką i traktowaniem tła, jednak przedstawienie wzburzonej wody jeziora - złożonej z ciemnych i jasnych plam barwnych - zdecydowanie zbliża je do siebie.

Grafiki z ostatniego zestawienia (rysunek 7 i 8) odpowiadają sobie natomiast przede wszystkim ze względu na aranżację i kompozycję całości. Na obu 


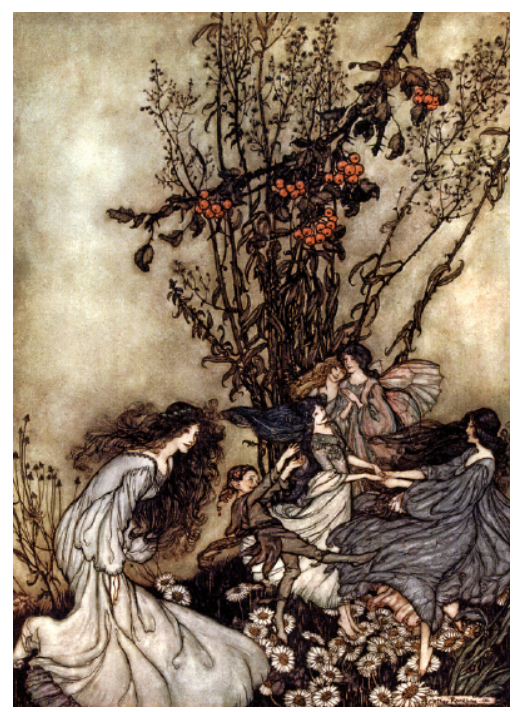

RYSUNEK 3. Arthur Rackham,

Fairies never say, "We feel happy"; what they say is, "We feel dancey"

(Peter Pan in Kensington Gardens).

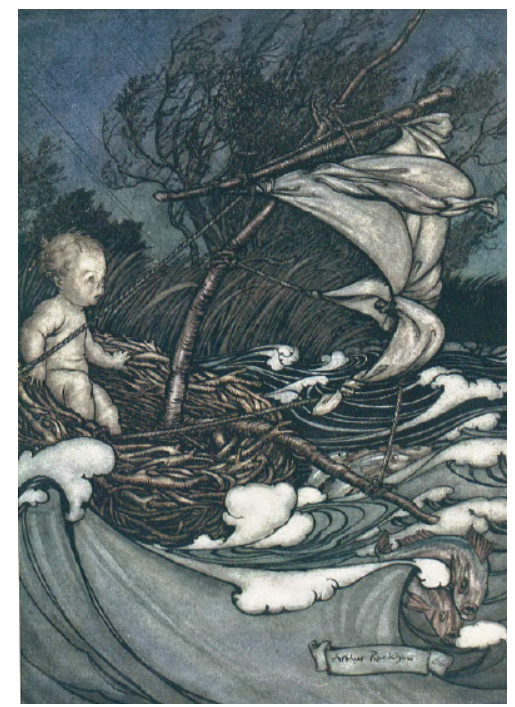

RYSUNEK 5. Arthur Rackham,

There now arose a mighty storm and he was tossed this way and that (Peter Pan in Kensington Gardens).

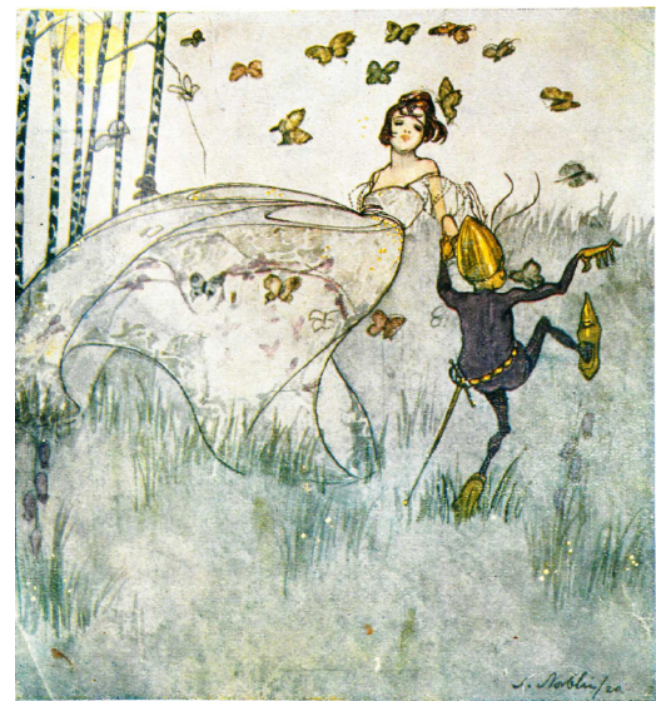

RYSUNEK 4. Stefan Norblin, ilustracja do rozdziału Uroczystość (Tajemnice motyli).

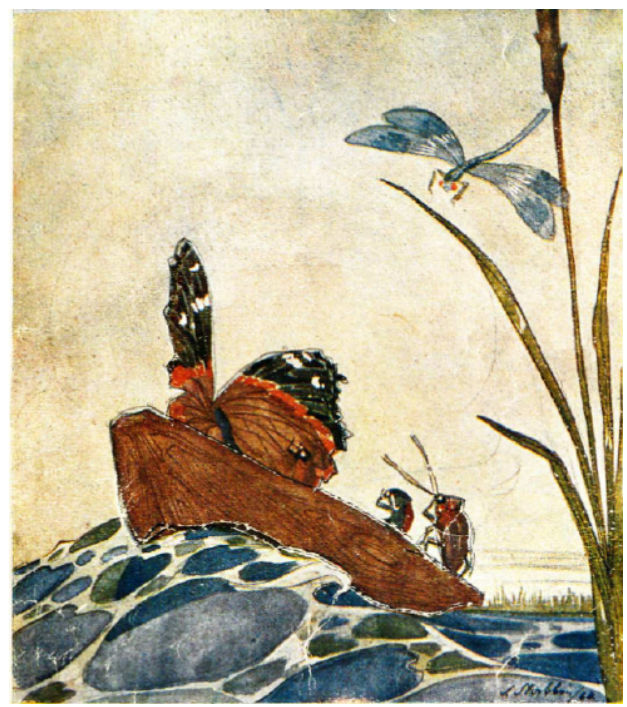

RYSUNEK 6. Stefan Norblin, ilustracja do rozdziału Na samotnej łódeczce (Tajemnice motyli). 


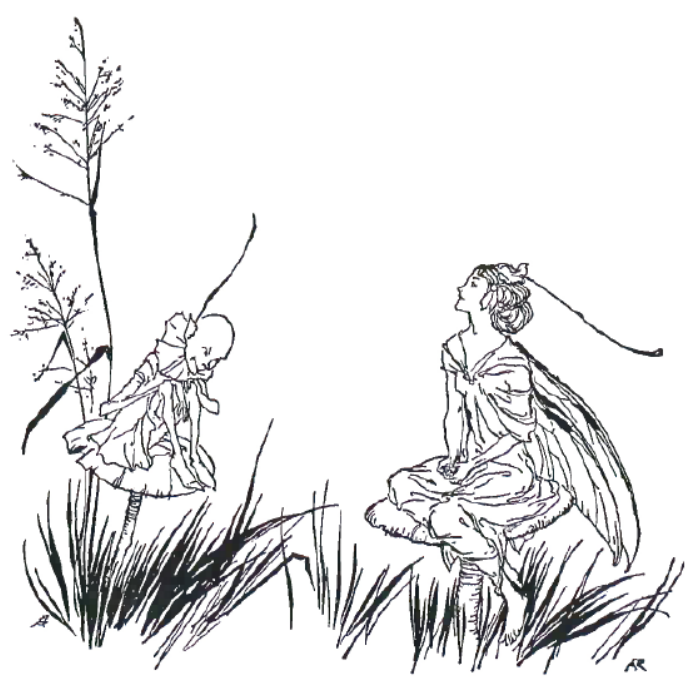

RYSUNEK 7. Arthur Rackham, winieta otwierająca rozdział Lock-out Time (Peter Pan in Kensington Gardens).

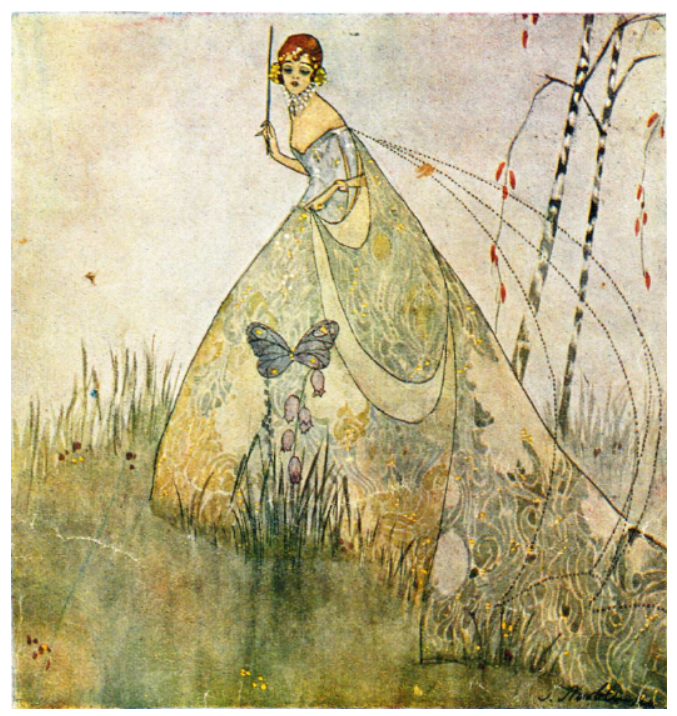

RYSUNEK 8. Stefan Norblin, ilustracja do rozdziału Motylek wierny łące (Tajemnice motyli).

rysunkach widać dwie postaci (wróżkę i elfa u Rackhama, królową łąk i motyla u Norblina), które w pewnym sensie zwracają się do siebie; scena odbywa się w wysokiej trawie, a swoistą jednostronną ramę ilustracji tworzy roślinność 
- wiechliny na grafice Rackhama, cienkie pnie brzóz u Norblina. Zwraca też uwagę welon, czy może przezroczyste skrzydła królowej łąk (zaznaczone przez Norblina delikatną, „kropkowaną” kreską), które układają się w linię odpowiadającą dokładnie linii złożonych skrzydeł wróżki z ilustracji Rackhama.

\section{Zakończenie. Więzy i sploty}

To wszystko każe przypuszczać, że w przypadku Tajemnic motyli można mówić o podwójnym zapośredniczeniu: nie tylko tekst wynika z twórczego przetworzenia inspiracji innym tekstem literackim w tłumaczeniu, lecz również szata graficzna zawiera nawiązania do ilustracji oryginału, który na grunt rodzimy dotarł poprzez przekład. Krąg twórców wielopoziomowo związanych z jednym utworem zacieśnia się tak, że można tu chyba mówić o rzadkim splocie więzów i pokrewieństw manifestujących się w dziele, choć trzeba zaznaczyć, że pokrewieństwa te wynikają wyłącznie z samej literatury i sztuki, gdyż w przypadku Szuchowej trudno o jakiekolwiek materiały pozaliterackie - nie istnieje archiwum pisarki, a jedynym „biograficznym” dowodem jej fascynacji opowieścią Barriego jest (być może) imię najstarszego syna - Piotrusia. Kwintet Barrie - Rackham - Rogoszówna - Szuchowa - Norblin można by zapewne jeszcze uzupełniać i poszerzać o innych „członków rodziny”, wykraczając już poza ramy dwudziestolecia, gdyż ścieżki, którymi zwykły przekradać się nawiązania i inspiracje literackie, przypominają raczej splątany labirynt przejść niż uładzone parkowe aleje. Od utworu szkockiego pisarza z początku XX wieku, poprzez wciąż popularne polskie tłumaczenie tego dzieła, można zawędrować do całkowicie zapominanego dzieła pisarki polskiego dwudziestolecia międzywojennego, która - jak głosi napis na jej nagrobku - „pracę i twórczość całego życia poświęciła dzieciom”. Utkane na kanwie opowieści Barriego Tajemnice motyli Szuchowej - z zachwycającymi grafikami Norblina - warto chyba jednak ocalić od zapomnienia wraz z ich pięknym językiem i niejednoznacznym przesłaniem, subtelnie mówiącym o mijającej „szczęśliwej godzinie”, którą trzeba chwytać - niczym motyla - w locie.

\section{Bibliografia}

Adamczyk-Garbowska, M. (1984). O książkach dla dzieci. Akcent, 4, 17-25.

Adamczyk-Garbowska, M. (1988). Polskie tłumaczenia angielskiej literatury dziecięcej. Problemy krytyki przekładu. Wrocław, Warszawa, Kraków: Zakład Narodowy im. Ossolińskich. 
b.a. (1928). Dobre Książki dla Młodzieży Towarzystwa Wydawniczego. W: O. Wilde, Prawdziwy przyjaciel. Opowiadania (M. Feldmanowa, tłum., s. 60). Warszawa, Kraków: Wydawnictwo J. Mortkowicza.

Bandura, L. (1930). Braki naszej literatury dziecięcej. Przyjaciel Szkoły, 20, 784-789.

Barrie, J. M. (1902). The little white bird or adventures in Kensington Gardens. London: Hodder \& Stoughton.

Barrie, J. M. (1906). Peter Pan in Kensington Gardens. London: Hodder \& Stoughton.

Barrie, J. M. (1913). Przygody Piotrusia Pana (Z. Rogoszówna, tłum.). Warszawa, Kraków: Wydawnictwo J. Mortkowicza. (wyd. oryg. 1906).

Barrie, J. M. (1928). Peter Pan, or the boy who would not grow up. London: Hodder \& Stoughton.

Barrie, J. M. (2006). Piotruś Pan i Wendy (M. Rusinek, tłum.). Kraków: Znak. (wyd. oryg. 1911).

Barrie, J. M. (2018). Piotruś Pan w Ogrodach Kensingtońskich (A. Wieczorkiewicz, tłum.). Poznań: Media Rodzina. (wyd. oryg. 1906).

Barrie, J. M. (scen.), Boucicault, D. (reż.), Frohman, C. (prod.). (1904, 27 grudnia). Peter Pan, or the boy who would not grow up. Przedstawienie na żywo w Duke of York's Theatre, London.

Białek, J. Z. (1979). Literatura dla dzieci i młodzieży w latach 1918-1939. Zarys monograficzny, materiały. Warszawa: WSiP.

Brentano, C. (1911). O Gdakaczu, Gdakuli i Gdakuleńce (Z. Rogoszówna, tłum.). Lwów: Księgarnia Polska Bernarda Połanieckiego. (wyd. oryg. 1838).

Czernow, A. M. (2018). „Umrzyj i narodź się na nowo”. W: K. Slany (red.), Śmierć w literaturze dziecięcej i młodzieżowej (s. 107-124). Warszawa: Naukowe i Edukacyjne SBP.

Dąbrowska, M. (1929). Zofija Żurakowska. Świat Książki, 4-5, 6-8.

France, A. (1915). Zazulka (Z. Rogoszówna, tłum.). Warszawa, Kraków: Wydawnictwo J. Mortkowicza. (wyd. oryg. 1883).

Heska-Kwaśniewicz, K. (2005). Zapomniani pisarze, zapomniane książki dla małego i młodego czytelnika. Katowice: Wydawnictwo UŚ.

Karpowicz, S., Szycówna, A. (1904). Nasza literatura dla młodzieży. Warszawa: Księgarnia Naukowa.

Kasprzak, A. (2014). Polish artist at the service of Maharajas. Art of the Orient, 3, 109-115.

Katajew, W. (1963). Wyprawa na poziomki (S. Szuchowa, tłum.). Warszawa: Nasza Księgarnia. (wyd. oryg. 1940).

Kłodkowski, P. (2012). Maharadża art déco. Tygodnik Powszechny, 18-19, 30-32.

Kowalczykówna, J. (1996). Schuchowa Stefania Jadwiga (1890-1972). W: W. Konopczyński (red.), Polski słownik biograficzny (t. 36, s. 20-21). Warszawa, Kraków: Instytut Historii im. Tadeusza Manteuffla PAN. 
Kowalczykówna, J. (2002). Szuchowa Stefania. W: B. Tylicka, G. Leszczyński (red.), Słownik literatury dziecięcej i młodzieżowej (s. 381). Wrocław, Warszawa, Kraków: Zakład Narodowy im. Ossolińskich.

Kozarzewska, M. (2009). Stefania Jadwiga Schuchowa (1890-1972). W: S. Werner (red.), Korzenie. Rody Wernerów, Norblinów, Schuchów, Malczów, Fukierów, Meisnerów (s. 253-266). Warszawa: Oficyna Wydawnicza Łośgraf.

Króliński, K. (1927). Braki i niedomagania naszej literatury dla dzieci i młodzieży. W: J. Z. Białek, Literatura dla dzieci i młodzieży w latach 1918-1939. Zarys monograficzny, materialy (s. 351-352). Warszawa: WSiP. (wyd. oryg. 1927).

Kulpińska, K. (2011). Sztuka i reklama. Twórczość Stefana Norblina w zakresie grafiki użytkowej. W: A. Szlązak (red.). Stefan Norblin 1892-1952. Artysta wszechstronny / Stefan Norblin 1892-1952: A master of many arts (T. Mirecki, tłum., s. 25-34). Stalowa Wola: Muzeum Regionalne.

Kwiatkowski, M. (1996). Schuch Jan Chrystian (1752-1813). W: W. Konopczyński (red.), Polski słownik biograficzny (t. 36, s. 16-17). Warszawa, Kraków: Instytut Historii im. Tadeusza Manteuffla PAN.

Makuszyński, K. (1932). Panna z mokra głową. Powieść dla młodzieży. Warszawa: Gebethner i Wolff.

Ministerstwo Wyznań Religijnych i Oświecenia Publicznego (1929). Szuchowa Stefania, Tajemnice motyli. W: Spis ksiażek poleconych do bibljotek szkolnych przez Komisję Oceny Książek do Czytania dla Młodzieży Szkolnej przy Ministerstwie Wyznań Religijnych i Oświecenia Publicznego w latach 1923 do 1928 włącznie (s. 305). Warszawa: Książnica Atlas.

Mortkowicz, J. (1929). Słowo wstępne. Świat Książki, 4-5, 3.

Mortkowicz-Olczakowa, H. (1962). Pod znakiem kłoska. Warszawa: PIW.

Porazińska, J. (1924). W Wojtusiowej izbie. Warszawa: Wydawnictwo M. Arcta.

Porazińska, J. (1955). Wiatr od Wisły leci górą. W: Psotki i śmieszki (s. 5). Warszawa: Nasza Księgarnia.

Rogosz-Walewska, J. (1961). Wspomnienie o Zofii Rogoszównie. Tygodnik Powszech$n y, 30,4$.

Rogoszówna, Z. (1910). Pisklęta. Kraków: Spółka Nakładowa „Książka”.

Rogoszówna, Z. (1911). Konfitury panny Michaliny. Warszawa: Nowe Wydawnictwo.

Rogoszówna, Z. (1920a). Sroczka kaszkę warzyła. W: Sroczka kaszkę warzyła. Gadki dziecięce, spisane z ust ludu i wspomnień dzieciństwa (s. 4). Lwów: Zakład Narodowy im. Ossolińskich.

Rogoszówna, Z. (1920b). Tańcowały dwa Michały. W: Sroczka kaszkę warzyła. Gadki dziecięce, spisane z ust ludu i wspomnień dzieciństwa (s. 20-21). Lwów: Zakład Narodowy im. Ossolińskich.

Rogoszówna, Z. (1925). Klituś Bajduś. Gadki, piosenki, zabawy dziecięce spisane z ust ludu i wspomnień dzieciństwa. Warszawa: Wydawnictwo M. Arcta. 
Rogoszówna, Z. (1928). Koszałki opałki. Gadki, piosenki, zabawy dziecięce spisała $z$ ust ludu i wspomnień dzieciństwa Zofja Rogoszówna. Warszawa: Wydawnictwo M. Arcta.

Rogoszówna, Z. (1930). Wesele Kuby. Warszawa: Nowe Wydawnictwo.

Schuch-Nikiel, Z. (2009). Jan Chrystian Schuch (1752-1813). W: S. Werner (red.), Korzenie. Rody Wernerów, Norblinów, Schuchów, Malczów, Fukierów, Meisnerów (s. 19-22). Warszawa: Oficyna Wydawnicza Łośgraf.

Sieradzka, A. (red.). (2011). Stefan Norblin. Stalowa Wola: Muzeum Regionalne. Skrobiszewska, H. (1973). Zofia Rogoszówna 1881(1882?)-1921. W: K. Wyka, A. Hutnikiewicz, M. Puchalska (red.), Literatura okresu Młodej Polski (t. 3, s. 621-631). Kraków: Wydawnictwo Literackie.

Slany, K. (2016). Groza w literaturze dziecięcej. Od Grimmów do Gaimana. Kraków: WN UP.

Szelburg-Zarembina, E. (1979). Kilka uwag o literaturze dla dzieci. W: J. Z. Białek, Literatura dla dzieci i młodzieży w latach 1918-1939. Zarys monograficzny, materiały (s. 402-405). Warszawa: WSiP. (wyd. oryg. 1934).

Szlązak, A. (red.). (2011). Stefan Norblin 1892-1952. Artysta wszechstronny / Stefan Norblin 1892-1952: A master of many arts (T. Mirecki, tłum.). Stalowa Wola: Muzeum Regionalne.

Szlązak, A. (2011). Wstęp. W: Stefan Norblin. Artysta trzech kontynentów. Stalowa Wola: Muzeum Regionalne.

Szuchowa, S. (1920). Tajemnice motyli. Warszawa: E. Wende i Ska.

Szuchowa, S. (1924). Szepty myszek. Warszawa: Składnica Pomocy Naukowych.

Szuchowa, S. (1929). Gospodarstwo Madzi i Jacka. Warszawa: Towarzystwo Wydawnicze „Rój”.

Szuchowa, S. (1948). Staszek kupuje nowe buty. Warszawa: Światowid.

Szuchowa, S. (1951). Zimowe szczęście. Warszawa: Nasza Księgarnia.

Szuchowa, S. (1956). Sieć i koszyczek. Warszawa: Nasza Księgarnia.

Szuchowa, S. (1958). Mateuszek na zaczarowanej wyspie. Warszawa: Filmowa Agencja Wydawnicza.

Szuchowa, S. (1958). Tajemnice motyli. Warszawa: Nasza Księgarnia. (wyd. oryg. 1920). Szuchowa, S. (oprac.). (1959a). Strach ma wielkie oczy. Bajka albańska. Warszawa: Nasza Księgarnia.

Szuchowa, S. (1959b). Tajemnica. W: Za milą trzecią (s. 7). Warszawa: Nasza Księgarnia. Szuchowa, S. (1959c). Za mila trzecią. Warszawa: Nasza Księgarnia.

Szuchowa, S. (1959d). Zabawa w parku. W: Za mila trzecia (s. 12-13). Warszawa: Nasza Księgarnia.

Szuchowa, S. (1960). Księżycowe piosenki. Warszawa: Ruch.

Szuchowa, S. (1960). Przygoda z małpką. Warszawa: Nasza Księgarnia. 
Szuchowa, S. (1966a). Dziwię się światu. Warszawa: Nasza Księgarnia.

Szuchowa, S. (1966b). Fontanna w parku. W: Dziwię się światu (s. 18). Warszawa: Nasza Księgarnia.

Szuchowa, S. (słowa), Wasowski, J. (muzyka). (1957, 22 kwietnia). Dobry pomyst Rudu$d u$. Warszawa: Polskie Radio.

Szymborska, K. (2013-2014). „Potłuczone kawałeczki nieśmiertelności” w Przygodach Piotrusia Pana J. M. Barriego. Filoteknos, 4, 204-218.

Wyspiański, S. (scen. i insc.), Walewski, A. (reż.). (1901, 16 marca). Wesele. Przedstawienie na żywo w Teatrze Miejskim, Kraków.

Thackeray, W. (1913). Pierścień i róża. Kraków: Wydawnictwo J. Mortkowicza. (wyd. oryg. 1855).

Werner, S. (2009). Korzenie. Rody Wernerów, Norblinów, Schuchów, Malczów, Fukierów, Meisnerów. Warszawa: Oficyna Wydawnicza Łośgraf.

Werner, S. (2009). Piotr Schuch (1918-1944). W: S. Werner (red.), Korzenie. Rody Wernerów, Norblinów, Schuchów, Malczów, Fukierów, Meisnerów (s. 171-178). Warszawa: Oficyna Wydawnicza Łośgraf.

Wieczorkiewicz, A. (2018). Piotruś Pan w Ogrodach Kensingtońskich Jamesa Matthew Barriego. Kontekst - Interpretacja - Przekład. Lublin: Wydawnictwo KUL.

Ziembiński, Z. (1928). O książkach do czytania dla młodzieży. Szkoła Powszechna, 2, 130-156. 